\title{
Tipping point towards biodiversity conservation? Local and global consequences of the application of 'Rights of Nature' by Ecuador
}

\author{
Authors: Juan M. Guayasamin ${ }^{1}$, Roo Vandegrift ${ }^{2}$, Tobias Policha ${ }^{2}$, Andrea C. Encalada ${ }^{1}$, \\ Natalia Greene ${ }^{3}$, Blanca Ríos-Touma ${ }^{4}$, Lorena Endara ${ }^{5}$, Rafael E. Cárdenas ${ }^{6}$, Fred \\ Larreátegui $^{7}$, Luis Baquero ${ }^{4}$, Inty Arcos $^{8}$, José Cueva ${ }^{9}$, Mika Peck ${ }^{10}$, Felipe Alfonso-Cortes ${ }^{11}$, \\ Daniel Thomas ${ }^{12}$, José DeCoux ${ }^{9}$, Elisa Levy ${ }^{9}$, Bitty A. Roy ${ }^{2}$
}

\section{Institutional affiliations}

${ }^{1}$ Universidad San Francisco de Quito USFQ, Instituto Biósfera, Colegio de Ciencias Biológicas y Ambientales, Laboratorio de Biología Evolutiva, Laboratorio de Ecología Acuática, Quito, Ecuador. Email: jmguayasamin@usfq.edu.ec

${ }^{2}$ Institute of Ecology and Evolution, University of Oregon, Eugene, OR, USA.

${ }^{3}$ Coordinadora Ecuatoriana de Organizaciones para la Defensa de la Naturaleza y el Medio Ambiente, CEDENMA and Global Alliance for the Rights of Nature.

${ }^{4}$ Grupo de Investigación en Biodiversidad, Medio Ambiente y Salud (BIOMAS), Universidad de Las Américas, Ecuador.

${ }^{5}$ Department of Biology, University of Florida, Gainesville, FL, 32611, USA.

${ }^{6}$ Museo de Zoología QCAZ, Laboratorio de Entomología, Escuela de Ciencias Biológicas, Facultad de Ciencias Exactas y Naturales, Pontificia Universidad Católica del Ecuador, Av. 12 de octubre 1076 y Roca, Apdo. 17-01-2184 Quito, Ecuador

${ }^{7}$ Lawyer, Larreategui \& Larreategui Abogados. Toledo N24-706 \& Coruña. Quito, Ecuador.

${ }^{8}$ Mancomunidad del Chocó Andino, Consorcio para el Desarrollo Sostenible de la Ecoregión Andina (CONDESAN), Fundación Imaymana, Ecuador.

${ }^{9}$ Estación Científica "Los Cedros", Cotacachi, Ecuador.

${ }^{10}$ Ecology, Behaviour and Environment, School of Life Sciences, University of Sussex, Brighton, UK.

${ }^{11}$ Fundación Naturaleza y Arte, Proyecto Washu, Quito, Ecuador.

${ }^{12}$ Independent researcher. Eichendorffring 86, 95447 Bayreuth, Germany

\begin{abstract}
In 2008, Ecuador recognized the Constitutional Rights of Nature in a global first. This recognition implies a major shift in the human-nature relationship, from one between a subject with agency (humans) and an exploitable object (Nature), to a more equilibrated relationship of respect. However, the lack of a standard legal framework has left room for subjective interpretations and variable implementation. The recent widespread concessioning of pristine ecosystems to mining industries in Ecuador has set up an unprecedented conflict and test of these rights. Currently, a landmark case involving Los Cedros Protected Forest
\end{abstract}


and mining companies has reached the Constitutional Court of Ecuador. If Ecuador's highest Court rules in favor of Los Cedros and the Rights of Nature, it would set a legal precedent with enormous impact on biological conservation in Ecuador and, potentially, the world. Such a policy shift offers a novel conservation strategy, through citizen oversight and action.

\section{Main text}

We are currently witnessing a potential tipping point in biodiversity conservation. Fittingly, this is taking place in front of the Constitutional Court of Ecuador, one of the most biodiverse countries on Earth (1) and the only one that grants rights for all of Nature at a constitutional level.

Biodiversity hotspots are facing threats from numerous human activities, and legislation usually falls short of effectively protecting endangered species and forest remnants. Under these scenarios, the legal framework that the Rights of Nature provides is a novel opportunity for biodiversity conservation, as well as citizen oversight and action.

\section{Rights of Nature}

Recognizing Nature as a legal entity with rights denotes a shift in the human-nature relationship, from one between a subject with agency (humans) and an exploitable object (Nature), to a relationship of mutual respect and tolerance $(2,3,4)$ (see the Figure 1). Articles 71-74 explicitly state that Nature has the right to "integral respect for its existence and for the maintenance and regeneration of its life cycles, structure, functions, and evolutionary processes." While all of the rights laid out in these articles are designed to protect Nature and the human populations that depend on it, Article 73 is of specific importance for the persistence of biodiversity. The first paragraph of Article 73 declares that "the State will apply preventive and restrictive measures on all activities that can lead to the extinction of species, the destruction of ecosystems or the permanent alteration of natural cycles."

The most important achievement of Article 73 is the constitutional recognition that Nature is no longer an object from the point of view of the Law, but an entity with its own rights. Furthermore, Article 10 establishes that Nature will have the rights that are recognized in the Constitution. The Constitution also tasks Ecuadorian citizens with the responsibility of respecting and looking after the Rights of Nature, as well as preserving a healthy environment (Article 83.6).

Under many environmental laws, Nature is considered property, and hence a resource to exploit, whereas Rights of Nature implies a goal of thriving, healthy ecosystems and human societies (see Figure 1). The difference is significant: environmental law treats Nature as an object and determines, for example, how much a human or human enterprise can pollute water. In contrast, under a Rights of Nature perspective, pollution should be avoided altogether because it affects the core of Nature's rights. Like a newborn child, Nature cannot represent itself. It needs a voice, legal guardians, and a seat at the negotiating table. Hence, 
the second paragraph of Article 71 in Ecuador's Constitution says that "all persons, communities, peoples, and nations can call upon public authorities to enforce the Rights of Nature."

\section{Conflict with Extractive Industries: the Case of Los Cedros Protected Forest}

Extractive industries, including mining and oil projects, cause serious biodiversity loss and environmental conflicts that are widespread in Latin America $(5,6,7)$. In addition to the direct impacts of mining, this industry is also a significant driver of deforestation. Clearing native forests for mineral exploration and extraction, and building new roads, opens new access to lands for colonization, hunting, and further forest clearing by settlers $(5,6,8)$. Mining in areas with high precipitation, such as tropical mountains, has damaged freshwater ecosystems with harms including erosion and excessive sediment loading and extremely high levels of heavy metal contamination (9).

In the last two years, there has been an escalating conflict between mining companies (the Canadian Cornerstone Capital Resources and its Ecuadorian partner ENAMI) and the megadiverse Los Cedros Protected Forest (hereafter Los Cedros). Los Cedros, established in 1994, is within the buffer zone of the Cotacachi Cayapas National Park and represents one of the last remnants of forest that once occurred in the Northwestern Andes of Ecuador. An estimated 500 species of woody tree exist in just the southeastern portion of Los Cedros that has been surveyed, an area less than 1000 hectares (data available on request); this can be compared to 454 tree species in all of Europe (12). The cloud forest of Los Cedros contains at least 148 species at some risk of extinction according to the Ecuador Red List; of these, 67 are also on the IUCN Red List (see supplementary materials). Several species known only from Los Cedros or its immediate surroundings face likely extinction if mining is allowed, including the Los Cedros rainfrog (Pristimantis cedros) and at least 12 orchid species (10, 11) (see the Figure 2 and supplementary materials). In addition to its incredible diversity, this protected forest supports many ecological functions and services. For instance, human settlements around Los Cedros practice sustainable agriculture (e.g., organic coffee) and, at the same time, foster community-based ecotourism, promoting the protection of headwater streams. These local sustainable practices, including small-scale reforestation, have increased in the last 20 years and recognize the essential human-nature interdependencies (13). If mining is endorsed, many of these local conservation practices will be lost.

Ecuador's forward thinking Constitution has been a theoretical exercise, until now. Many constitutional provisions with regards to the Rights of Nature have not been effectively enforced and at times have been willfully ignored. Ecuadorian and international scientists and advocates have taken on the case of mining concessions in Los Cedros and worked through the lower courts to protect the biodiversity and associated ecosystem services of this remarkable region (see the supplementary materials). Now the case is before the Constitutional Court and represents a true test of the "Rights of Nature" articles of the Constitution. The Court is expected to pronounce its verdict during the coming weeks. 


\section{Regional and Global Implications for Conservation}

If Ecuador's Constitutional Court rules in favor of Los Cedros, it would set a legal precedent with enormous impact for biological conservation in Ecuador, Latin America, and, potentially, the world.

In Ecuador, recent mining concessions cover more than 13\% of Ecuador's territory, often overlapping with the last remnants of megadiverse Andean tropical forests, more than two million hectares of which were thought to be preserved due to having protected forest designation (11) (see Figure 2). With an ongoing, regional economic crisis exacerbated by the COVID-19 pandemic, several countries have, in practice, relaxed environmental standards in favor of extractive activities $(14,15)$. Under this situation, numerous local communities and NGOs have come forward to protect the forests and the ecological services that they provide. A ruling favoring Los Cedros would be a powerful precedent that will surely trigger similar actions towards the protection of endangered ecosystems across the country, creating, for the first time, a possibility of real and effective citizen action towards environmental enforcement.

At the regional scale, political and economic pressures around these issues in Latin America are extremely strong, and there are similar ongoing conflicts between extractive industry and diminishing ecosystems in several neighboring countries. Legal innovations around the Rights of Nature are currently being explored elsewhere in the region (e.g., Colombian courts have recently extended rights to certain river systems in that country). The precedent set by the Los Cedros case will likely influence other countries to adopt similar views on the Rights of Nature. Expansion and recognition of the Rights of Nature throughout Latin American could also be a tool of social justice, as it legitimizes the ongoing efforts of citizens and indigenous groups to defend Nature as a subject of the law.

At the global level, a ruling in favor of the Rights of Nature would set an example that could be followed by other countries or intergovernmental organizations, including the United Nations. There is already a signature campaign and civil society initiative pushing the UN to adopt a 'Declaration for the Rights of Mother Earth', calling countries to be the champions for this initiative. It is important for the world to reflect on the limits of Nature and to seriously question the effectiveness of current conservation policies and actions. Policy frameworks that place humans in context as a part of Nature, integrated into a system that balances intrinsic rights between legitimate subjects of the Law, rather than placing humans as above, or apart from, Nature, will be a necessary part of addressing the serious issues facing our planet in the near future.

There is a pressing need to establish stronger and more effective conservation strategies. Ensuring legal protection for the Rights of Nature offers us one such strategy, which may be particularly effective because of the way that it would empower the citizens of the world to act as stewards and guardians of Nature. Given the rates of deforestation and the realities of global climate change, the need for such a policy shift is now more urgent than ever $(7,14$, 15). 


\section{Legislation}

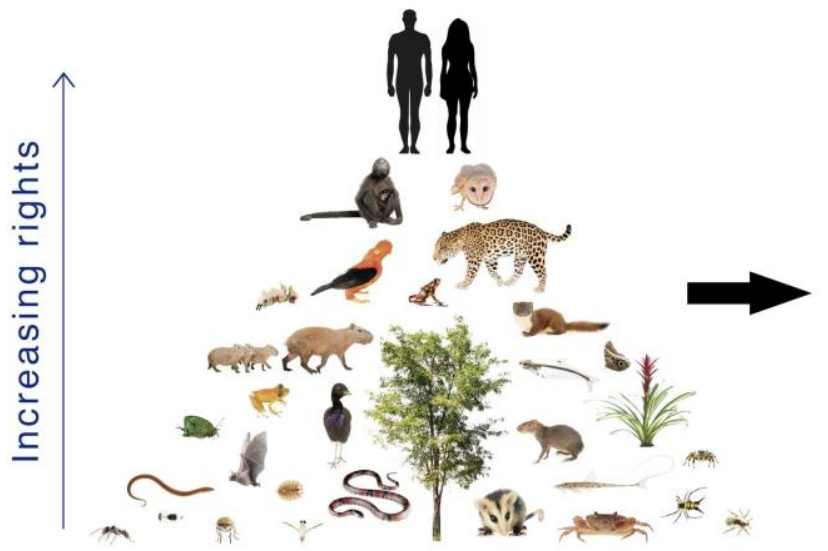

Anthropocentric

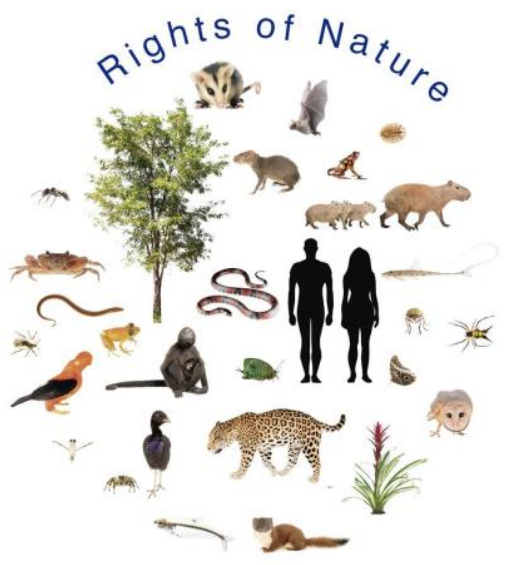

Ecocentric

Figure 1. Recognizing that Nature has rights denotes a shift in the human-nature relationship, from one between a subject with agency (humans) and an exploitable object (Nature), to a relationship of mutual respect and tolerance, towards permanent coexistence.

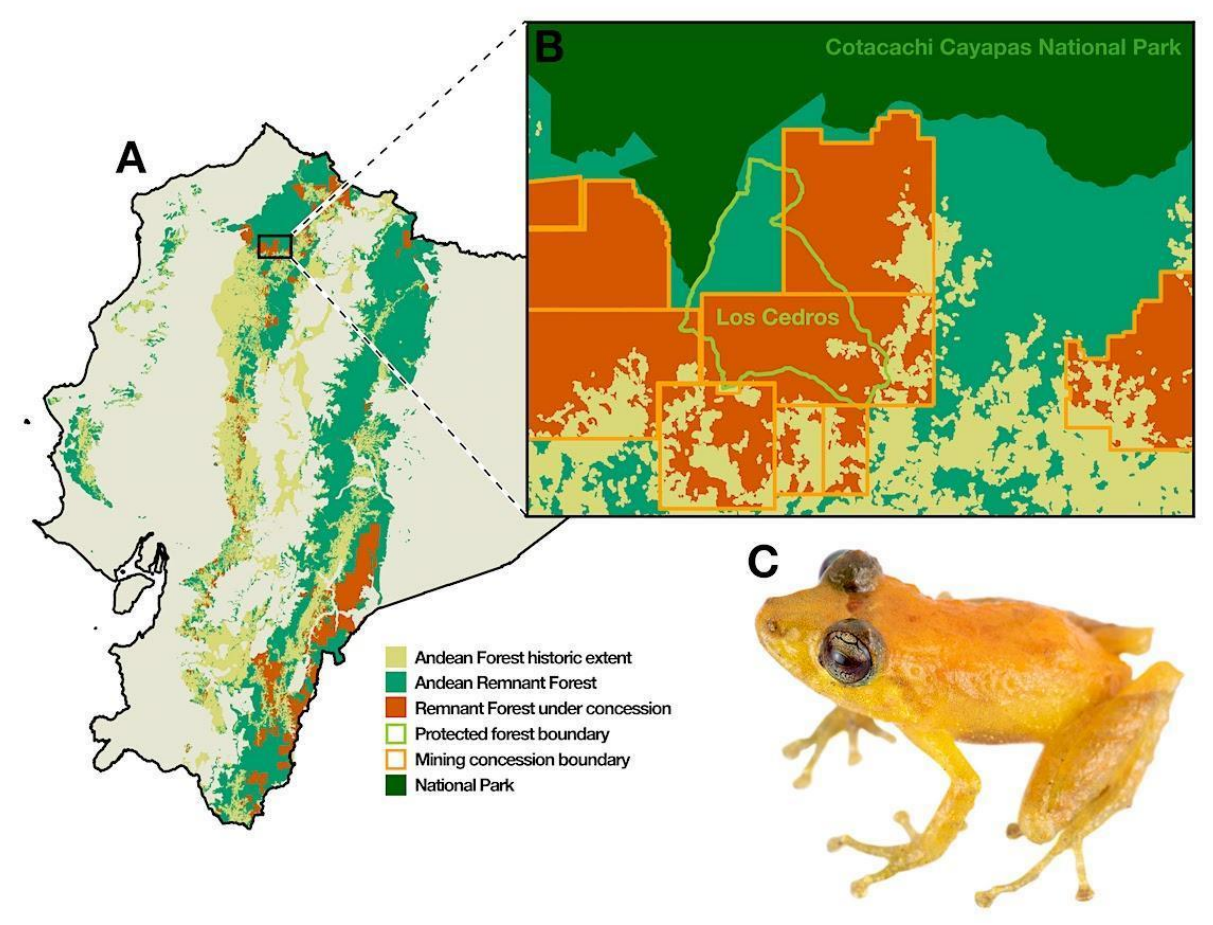

Figure 2. Conflict between mining activities and biodiverse ecosystems. (A) Remnant native Andean forest in Ecuador (green; data from the Ecuadorian Ministry of Environment), showing deforestation on the western slope of the Andes (yellow), and overlap between remnant forest and current mining concessions (red; data from the Ecuadorian Agency for the Control and Regulation of Mines). (B) Inset, showing the area around Los Cedros; note the overlap between mining concessions and remnant forests. (C) The Los Cedros rainfrog (Pristimantis cedros) is one of hundreds of known endemic and endangered species documented from Los Cedros (see supplementary materials). This frog is only 
known from Los Cedros and the nearby Río Manduriacu Reserve, areas concessioned to two mining companies (the Canadian Cornerstone Capital Resources, and the Anglo-Australian BHP Billiton).

\section{Acknowledgments}

We thank Mary E. Powers for her comments on the manuscript. J.M.G. acknowledges support from Universidad San Francisco de Quito (HUBI 16808, 16871). B.R.T acknowledges support from Universidad de Las Américas, Ecuador (AMB.BRT.19.02). Photos in Figure 1 were provided by Jose Vieira/Ex-Situ/Tropical Herping. Photo in Figure 2C was provided by Jaime Culebras.

\section{Literature Cited}

1. R. A. Mittermeier, C. G. Mittermeier, E. O. Wilson, Megadiversity: Earth's biologically wealthiest nations (CEMEX/Agrupación Sierra Madre, Mexico City, 2005).

2. Asamblea Constituyente de Montecristi, Constitución de la República del Ecuador (2008), (available at http://biblioteca.defensoria.gob.ec/handle/37000/823).

3. S. G. Laastad, Nature as a Subject of Rights? National Discourses on Ecuador's Constitutional Rights of Nature. Forum for Development Studies. 0, 1-25 (2019).

4. L. J. Kotzé, P. Villavicencio Calzadilla, Somewhere between rhetoric and reality: Environmental constitutionalism and the rights of nature in Ecuador. Transnational Environmental Law. 6, 401 (2017).

5. N. L. Alvarez-Berríos, T. M. Aide, Global demand for gold is another threat for tropical forests. Environ. Res. Lett. 10, 014006 (2015).

6. J. Lessmann, J. Fajardo, J. Muñoz, E. Bonaccorso, Large expansion of oil industry in the Ecuadorian Amazon: biodiversity vulnerability and conservation alternatives. Ecology and Evolution. 6, 4997-5012 (2016).

7. B. J. Cardinale, J. E. Duffy, A. Gonzalez, D. U. Hooper, C. Perrings, P. Venail, A. Narwani, G. M. Mace, D. Tilman, D. A. Wardle, A. P. Kinzig, G. C. Daily, M. Loreau, J. B. Grace, A. Larigauderie, D. S. Srivastava, S. Naeem, Biodiversity loss and its impact on humanity. Nature. 486, 59-67 (2012).

8. J. Lessmann, M. J. Troya, A. S. Flecker, W. C. Funk, J. M. Guayasamin, V. OchoaHerrera, N. L. Poff, E. Suárez, A. C. Encalada, Validating anthropogenic threat maps as a tool for assessing river ecological integrity in Andean-Amazon basins. PeerJ. 7, e8060 (2019).

9. K. M. Wantzen, J. H. Mol, Soil Erosion from Agriculture and Mining: A Threat to Tropical Stream Ecosystems. Agriculture. 3, 660-683 (2013).

10. L. Endara, L. Jost, in Libro rojo de las plantas endémicas del Ecuador, S. León-Yánez, R. Valencia, N. Pitman, L. Endara, C. U. Ulloa, H. Navarrete, Eds. (Herbario QCA, Pontificia Universidad Católica del Ecuador, Quito, Ecuador, ed. 2, 2019; https://bioweb.bio/floraweb/librorojo/home), pp. 441-702.

11. B. A. Roy, M. Zorrilla, L. Endara, D. C. Thomas, R. Vandegrift, J. M. Rubenstein, T. Policha, B. Rios-Touma, M. Read, New mining concessions could severely decrease biodiversity and ecosystem services in ecuador. Tropical Conservation Science. 11, 1940082918780427 (2018). 
12. M. Rivers, E. Beech, I. Bazos, F. Bogunić, A. Buira, D. Caković, A. Carapeto, A. Carta, B. Cornier, G. Fenu, F. Fernandes, P. Fraga i Arguimbau, P. Garcia Murillo, M. Lepší, M. Matevski, F. Medina, M. Menezes de Sequeira, N. Meyer, V. Mikoláš, C.

Montagnani, T. Monteiro-Henriques, J. Naranjo Suárez, S. Orsenigo, A. Petrova, A. Reyes-Betancort, T. Rich, T. Salvesen, P. H. Salvesen, I. Santana López, S. Scholz, A. Sennikov, L. Shuka, L. F. Silva, P. Thomas, A. Troia, J. L. Villar, D. Allen, European Red List of Trees (International Union for Conservation of Nature and Natural Resources (IUCN), 2019; https://helda.helsinki.fi/handle/10138/317384).

13. L. D'Amico, in Water, Cultural Diversity, and Global Environmental Change: Emerging Trends, Sustainable Futures?, B. R. Johnston, L. Hiwasaki, I. J. Klaver, A. Ramos Castillo, V. Strang, Eds. (Springer Netherlands, Dordrecht, 2012; https://doi.org/10.1007/978-94-007-1774-9_30), pp. 433-452.

14. D. C. Daly, Opinion: We have been in lockdown, but deforestation has not. Proc Natl Acad Sci USA. 117, 24609 (2020).

15. B. Roche, J.-F. Guégan, Ecosystem dynamics, biological diversity and emerging infectious diseases. Comptes Rendus Biologies. 334, 385-392 (2011). 